\title{
Airway obstruction due to late-onset angioneu- rotic edema from angiotensin-converting enzyme inhibition
}

Ali Mchaourab MD, Constantine Sarantopoulos MD PhD DEAA, David F. Stowe MD PhD

Purpose: Angioneurotic edema is a well-documented complication of angiotensin-converting enzyme inhibitors (ACEI). We report a case of acute airway obstruction from a late-onset, probable ACEI-related angioneurotic edema and its subsequent management.

Clinical features: A 48-yr-old obese man presented for transurethral resection of a bladder tumour (TURBT). His past medical history included hypertension controlled with hydrochlorothiazide and quinapril which had been started 13 mo earlier. Previous surgery was uncomplicated. Midazolam was used for premedication and for intraoperative sedation together with fentanyl and propofol. After uneventful spinal anesthesia with bupivacaine, operation and recovery, he was transferred to the floor. Five hours later he developed severe edema of his face, tongue and neck, with drooling, that progressed into airway obstruction and respiratory arrest. Ventilation was restored via immediate cricothyroidotomy, and a subsequent tracheotomy was completed uneventfully in the operating room. His serum $\mathrm{Cl}$ esterase inhibitor levels at $\mathrm{I}, 5$ and 23 days later were normal. The angioneurotic edema was attributed to the ACEl treatment. The edema resolved after $48 \mathrm{hr}$, and further follow-up was unremarkable.

Conclusion: This observation is consistent with other reports that angioneurotic edema from ACEI can occur many months after the initiation of treatment. This can involve the airway and may produce life-threatening respiratory compromise. Physicians should be aware of this association and the possible need for immediate surgical intervention for the establishment of an airway in case of worsening edema or respiratory arrest.

Objectif : L'œdème angioneurotique est une complication bien documentée des inhibiteurs de l'enzyme de conversion de l'angiotensine (IECA). Nous présentons un cas d'obstruction aiguë des voies aériennes causée par un œdème angioneurotique, probablement relié aux IECA, et son traitement subséquent.

Eléments cliniques : Un homme de 48 ans, obèse, s'est présenté pour une résection transurétrale d'une tumeur à la vessie (RTUTV). Ses antécédents incluaient de l'hypertension contrôlée depuis 13 mois par de l'hydrochlorothiazide et du quinapril. Une intervention chirurgicale antérieure s'était bien déroulée. Le midazolam avait été utilisé en prémédication et comme sédation peropératoire avec du fentanyl et du propofol. Après la rachianesthésie sans incident avec de la bupivacaine, l'opération et la récupération, le patient a été transféré à sa chambre. Cinq heures plus tard, il a développé un important œedème du visage, de la langue et du cou, accompagné d'hypersalivation, qui a provoqué une obstruction des voies aériennes et un arrêt respiratoire. La ventilation a été restaurée par une cricothyroïdotomie immédiate, et une trachéotomie subséquente a été pratiquée sans incident dans la salle d'opération. Son niveau d'inhibiteur d'estérase $\mathrm{Cl}, 1,5$ et 23 jours plus tard, était normal. La cause de l'œdème angioneurotique a été attribuée au traitement IECA. L'œè̀me est disparu après $48 \mathrm{~h}$ et le suivi a été sans particularité.

Conclusion : Ce cas confirme d'autres observations du fait que l'œdème angioneurotique causé par les IECA peut survenir de nombreux mois après le traitement initial. Cet œdème peut atteindre les voies aériennes et compromettre gravement la respiration. Les médecins doivent connaître l'association de ces conditions et la possibilité d'une intervention chirurgicale immédiate nécessaire au rétablissement de la liberté des voies aériennes en cas d'aggravation de l'œdème ou d'un arrêt respiratoire.

Address correspondence to: Dr. Ali Mchaourab, Department of Anesthesiology, Medical College of Wisconsin, 8701 Watertown Plank Road, Milwaukee, WI 53226, USA: Phone: 414-456-5735; Fax: 414-456-6507; E-mail: alimch@mcw.edu Accepted for publication July 3, 1999 
A NGIONEUROTIC edema is a well-documented complication of antihypertensive therapy with angiotensin-converting enzyme inhibitors (ACEI), such as quinapril. ${ }^{1}$ We report a case of life-threatening, acute airway obstruction from delayed onset ACEI-related angioneurotic edema 13 mo after initiation of therapy and its subsequent management.

\section{Case report}

A 48 -yr-old, $118 \mathrm{~kg}, 182 \mathrm{~cm}$, moderately obese man with gross hematuria presented for transurethral resection of transitional cell carcinoma of the bladder. His recent history and review of systems were otherwise negative or unremarkable. His medical history was positive only for alcoholism in the remote past, depression, and hypertension currently controlled with $25 \mathrm{mg}$ hydrochlorothiazide po and $10 \mathrm{mg}$ quinapril po daily. Quinapril had been started 13 mo before the current admission and continued up to the day of surgery. Other medications included $100 \mathrm{mg}$ sertraline po and $0.25 \mathrm{mg}$ alprazolam po daily. Previous surgical procedures included a left nephrectomy three years ago under general anesthesia, and two TURBT three and one year ago under general and spinal anesthesia respectively. All were uneventful. Family history was unremarkable or non-contributory. Physical examination and laboratory findings were also unremarkable, with the exception of elevated BUN (34 $\left.\mathrm{mg} \cdot \mathrm{dL}^{-1}\right)$ and creatinine $\left(1.7 \mathrm{mg} \cdot \mathrm{dL}^{-1}\right)$. Hematocrit was $42.9 \%$ and sodium and potassium concentrations were 142 and $3.8 \mathrm{mmol} \cdot \mathrm{L}^{-1}$, respectively.

Standard monitoring was applied, and $2 \mathrm{mg}$ midazolam $i v$ was administered as premedication. Spinal anesthesia was performed by injecting $13.5 \mathrm{mg}$ hyperbaric bupivacaine via a 22 gauge Quincke needle at $\mathrm{L}_{3-4}$. The surgical procedure included TURBT and right ureteroscopy and lasted $2.5 \mathrm{hr}$. The patient was sedated intraoperatively with $3 \mathrm{mg}$ midazolam iv total, $100 \mu \mathrm{g}$ fentanyl total, and $25-75 \mu \mathrm{g} \cdot \mathrm{kg}^{-1} \cdot \mathrm{min}^{-1}$ propofol. Three litres of sterile water were used to irrigate the bladder. Blood loss was difficult to estimate, and 2,100 $\mathrm{ml}$ saline were given $i v$. Throughout the procedure, the patient breathed $3 \mathrm{~L} \cdot \mathrm{min}^{-1}$ oxygen via a nasal cannula. He did not show any evidence of airway obstruction, respiratory distress, or hemodynamic instability. The immediate postoperative course in the postanesthesia care unit (PACU) was uneventful, and the patient was transferred to his room $2.5 \mathrm{hr}$ later.

No medication was given to the patient in the PACU or after admission to the floor. Five hours after the completion of surgery, the patient was found sitting on the bed in respiratory distress. Considerable edema of the face and neck as well as drooling were noted. Repeated attempts were made to suction oral secretions and, because of worsening stridor, $0.5 \mathrm{mg}$ epinephrine $s c$ was given twice, along with $50 \mathrm{mg}$ diphenhydramine $i v$. Within five minutes, symptoms and signs consistent with upper airway obstruction developed, cyanosis and respiratory arrest followed, and the emergency resuscitation procedures were initiated. The presence of severe purple edema of the face and neck and protrusion of a severely edematous tongue were noted. Direct laryngoscopy for tracheal intubation was not attempted. Instead, an immediate cricothyroidotomy via a horizontal incision was performed urgently and a 7.5 ID endotracheal tube was placed in the trachea. The lungs were ventilated with $1.0 \mathrm{FiO}_{2}$ through a resuscitation bag (AMBU), and bilateral breath sounds were noted. An initial hemoglobin saturation $\left(\mathrm{SpO}_{2}\right)$ reading of $78 \%$ was obtained. Then, $125 \mathrm{mg}$ thiopental and $5 \mathrm{mg}$ midazolam were given $i p$. The $\mathrm{SpO}_{2}$ increased to $95 \%$, and the patient was transferred to the operating room to complete a tracheotomy. Preoperative arterial blood analysis while breathing $1.0 \mathrm{FiO}_{2}$ showed $\mathrm{pH}$ of 7.2, $\mathrm{PaCO}_{2}$ of $63 \mathrm{mmHg}, \mathrm{PaO}_{2}$ of $92 \mathrm{mmHg}$, hemoglobin saturation of $95 \%$ and bicarbonate concentration of 25 $\mathrm{mmol} \cdot \mathrm{L}^{-1}$. Sodium and potassium concentrations were $139 \mathrm{mmol} \cdot \mathrm{L}^{-1}$ and $3.5 \mathrm{mmol} \cdot \mathrm{L}^{-1}$, respectively.

The intraoperative course was uneventful. The lungs were easily mechanically ventilated with an $\mathrm{FiO}_{2}$ of 1.0 and an $\mathrm{SpO}_{2}$ of $100 \%$ was maintained. Postoperatively, the patient was transferred to the Intensive Care Unit and treated with $50 \mathrm{mg}$ diphenhydramine and $100 \mathrm{mg}$ hydrocortisone iv. Angiotensin-converting enzyme inhibitor therapy was discontinued. The edema resolved completely over the next $48 \mathrm{hr}$; no adverse neurological or cardiac consequences were documented, and the patient was discharged home six days later. His $\mathrm{Cl}$ esterase inhibitor levels measured 1,5 and 23 days later were found to be normal and qualitatively functional. The patient was doing well upon further follow-up two months later.

\section{Discussion}

Angioneurotic edema is a demarcated, painless, nonpruritic, non-pitting edema of the deep dermis and subcutaneous tissue, usually involving the face, upper airway, gastrointestinal tract and extremities. It can be hereditary and secondary to $\mathrm{Cl}$ esterase inhibitor deficiency; but most commonly it occurs in sporadic, idiopathic forms which affect up to $10 \%$ of the population. Angioneurotic edema can be precipitated by a variety of environmental or pharmacological factors. ${ }^{1}$

Angiotensin-converting enzyme inhibitors (ACEI) commonly used for the treatment of hypertension and 
congestive heart failure are associated with an incidence of angioneurotic edema from 0.1 to $2 \%{ }^{1}$ Although a retrospective study of 36,000 patients showed that $60-70 \%$ of the incidences occurred in the first week of administration, ${ }^{1}$ other publications have shown that late onset (up to one year after initiation of therapy) is also possible., ${ }^{2,3}$

Angioneurotic edema crisis is believed to occur as a result of inhibition of angiotensin-converting enzyme (ACE), and the subsequent block of metabolism of bradykinin and substance $P$, which are also metabolized by the same enzyme. ${ }^{4,5}$ Both of these substances can mediate the reactions of vasodilatation, increased capillary permeability and edema formation. ${ }^{6}$ Angioneurotic edema in conjunction with ACEI can produce severe airway obstruction, ${ }^{7}$ respiratory distress, ${ }^{8}$ and death. ${ }^{9}$

We attributed the upper airway obstruction in our patient to a late-onset attack of angioneurotic edema resulting from ACEI treatment initiated 13 mo before the incident. Other possible etiological associations were ruled out from the negative family and past medical history, as well as the negative testing for $\mathrm{Cl}$ esterase inhibitor deficiency. The presentation of symptoms and signs such as dyspnea, tongue swelling, drooling, and purple facial edema are recognized manifestations of the disease. ${ }^{1,2}$ However, the events and the exact etiological associations which precipitated the crisis are unclear. Jain $t$ al. recognized obesity, a history of previous face and neck surgery, and prior intubation as risk factors. ${ }^{3}$ The interaction of the above factors and edema from bradykinin activation can result in a relatively narrowed airway that can evolve into severe obstruction. Of these risk factors, only obesity was present in our patient. However, we do not believe that obesity solely contributed to the angioneurotic edema in the absence of prior facial surgery or tracheal intubation. The association of airway instrumentation and precipitation of angioneurotic edema has been documented. ${ }^{10}$ In our patient, it is possible that attempts to suction secretions from the oropharynx may have precipitated a severe attack on the basis of a subclinical mild degree of airway soft tissue edema. This might have resulted from excessive absorption of water from irrigation of the bladder, so this constitutes a remote possibility.

Codeine can lead to generation of tissue bradykinin from mast cell degranulation, ${ }^{6}$ constituting thus another risk factor. However, in reviewing the patient's profile, no codeine or postoperative analgesics were administered to him.

Regardless of the etiological speculations, the urgent management of the airway was the most appropriate task under the clinical circumstances. It was considered that attempts at laryngoscopy and oral intubation of the trachea would have been too risky. Although medical management (epinephrine and diphenhydramine) had been tried previously, it was the emergency cricothyroidotomy that proved to be life-saving. Available literature indicates that our action was the most appropriate for the most severe cases of angioneurotic edema when respiratory arrest ensues. ${ }^{2,7}$ Further management included observation in the ICU and treatment with antihistamine drugs and corticosteroids, which has also been reported. ${ }^{2,7,10}$

No other angioneurotic edema crisis has been reported to occur 13 mo after the initiation of ACEI therapy. This presentation, typical for a late-onset angioneurotic edema from ACEI, indicates the need for physicians to be aware of the potential for such complications in patients treated with ACEI. Angioneurotic edema may occur many months after initiation of treatment, but it may be difficult to recognize because of a lack of a definite temporal correlation. Events such as airway instrumentation and codeine administration can be precipitating factors. Immediate surgical intervention may be necessary to restore ventilation in the situation of worsening edema or respiratory compromise.

\section{Acknowledgments}

The authors wish to thank Angela Barnes for assistance in preparation of this manuscript.

\section{References}

1 Slater EE, Merill $D D$, Guess $H A$, et al. Clinical profile of angioedema associated with angiotensin convertingenzyme inhibition. JAMA 1988; 260: 967-70.

2 Weng $P-K$, Wang $H-W$, Lin $J K, S u W-\Upsilon$. Late-onset lifethreatening angioedema and upper airway obstruction caused by angiotensin-converting enzyme inhibitor: report of a case. Ear Nose Throat 1997; 76: 404-7.

3 Jain $M$, Armstrong $L$, Hall J. Predisposition to and late onset of upper airway obstruction following angiotensin-converting enzyme inhibitor therapy. Chest 1992; 102: 871-3.

4 Regoli D, Barabe J. Pharmacology of bradykinin and related kinins. Pharmacol Rev 1980; 32: 1-46.

5 Casceiri MA, Bull HG, Mumford RA, Patchett $A A$, Thornberry NA, Liang T. Carboxyl-terminal tripeptidyl hydrolysis of substance $\mathrm{P}$ by purified rabbit lung angiotensin-converting enzyme and the potentiation of substance $P$ activity in vivo by captopril and MK 422 . Mol Pharmacol 1983; 25: 287-93.

6 Anderson $M W$, de Shazo RD. Studies of the mechanism of angiotensin-converting enzyme(ACE) inhibitorassociated angioedema: the effect of an ACE inhibitor on cutaneous responses to bradykinin, codeine, and 
histamine. J Allergy Clin Immunol 1990; 85: 856-8.

7 Barna JS, Frable MAS. Life-threatening angioedema. Otolaryngol Head Neck Surg 1990; 103: 795-8.

8 Jett GK. Captopril-induced angioedema. Ann Emerg Med 1984; 13: 489-90.

9 Suarez $M, H o$ PWL, Johnson ES, Perez G.

Angioneurotic edema, agranulocytosis, and fatal septicemia following captopril therapy. Am J Med 1986; 81: 336-8.

10 Kharasch $E D$. Angiotensin-converting enzyme inhibitor-induced angioedema associated with endotracheal intubation. Anesth Analg 1992; 74: 602-4. 